\title{
That oestrogen replacement for osteoporosis prevention should no longer be a bone of contention
}

\author{
T G Palferman
}

Virginia Woolf was contemptuous of much that was written about women by men ${ }^{1}$ and believed their motives were based largely on anger. The hypothesis now proposed, that effective treatment to protect women from the misery of osteoporosis should be more actively promoted, would perhaps have made some amends and met with approbation from the lady of Bloomsbury.

More than half a century since Fuller Albright observed a relation between osteoporosis and oestrogen deficiency ${ }^{2}$ only a minority of postmenopausal women today receive oestrogen replacement therapy. ${ }^{3}$ Popularity among potential recipients and their doctors has waxed and waned as difficulties in evaluating risks and benefits have sown the seeds of confusion and controversy. There is now substantial evidence in favour of beneficial effects on many counts and for protection against osteoporosis, in particular. (For the purpose of this article oestrogen replacement therapy whether taken alone or in combination with progestogens is synonymous with hormone replacement therapy-HRT.)

Bone mineral content and bone mineral density (BMD) begin to decline in early mid-life along with natural aging in other systems. During the first decade of the menopause an accelerated phase of bone loss is superimposed on the involutional reduction in BMD.

There are now ample data to demonstrate that BMD falls in proportion to declining oestrogen levels with resultant increase in fracture risk. ${ }^{4-8}$ Conversely, oestrogen replacement preserves bone mass and reduces fracture risk ${ }^{9-16}$ with its protective effect greater the earlier HRT is introduced. ${ }^{17}$ The results of four international conferences on osteoporosis have concluded that oestrogen replacement is the most important mode of primary prevention of hip fracture. ${ }^{18-21}$ Therapeutic intervention at the menopause, therefore, offers the greatest opportunity to preserve BMD.

That such intervention is warranted can be appreciated from the mass of statistics available for England and Wales. Ir: 1985 about 46000 hip fractures were treated. If current demographic trends continue the year 2006 will see a doubling of this figure. ${ }^{22}$ The cost in 1988 to an already stretched health service has been estimated at $£ 160$ million. ${ }^{22}$ Twenty per cent of orthopaedic beds are presently occupied by elderly patients who have had femoral neck fractures, ${ }^{22}$ which is a death sentence for one in five. For many it is the loss of a fragile independence while the majority have not returned to their previous functional capacity after 12 months. ${ }^{23-25}$ In the sixth decade one in four women have an osteoporosis-related fracture, the figure doubling by the age of $70 .^{26}$

Oestrogens: benefits and modes of action The mechanisms by which the beneficial effects of oestrogen on bone cited above are achieved are complex. Oestrogen receptors have been found on osteoblasts; ${ }^{27-29}$ local proliferation of osteoblast-like cells and induction of growth factors are mediated by cytokines under local oestrogen control, ${ }^{30-32}$ - the circulating hormone probably influences calcitonin levels and vitamin $\mathrm{D}_{3}$ activity. Those oestrogens used in HRT preparations are so-called 'natural' hormones as they are identical to endogenous oestrogens in their action. Of these, oestradiol and oestrone are manufactured, whereas the naturally occurring conjugated equine oestradiols are extracted from the urine of pregnant mares. These are in contrast with the synthetic oestrogens, such as ethinyl oestradiol, used in the oral contraceptive pill, which have a biological activity of between 80 and 200 times greater than that of the natural hormone. More efficient suppression of follicle stimulating hormone thereby ensuring contraceptive effectiveness. An appreciation of these differences is necessary in order to understand the separate side effect profiles.

The doses of oestrogens which protect against osteoporosis are $0.625 \mathrm{mg}$ conjugated oestrogen, ${ }^{33} 2 \mathrm{mg}$ oral oestradiol, ${ }^{34}$ or $50 \mu \mathrm{g}$ of oestradiol by patch. ${ }^{35}$

As rheumatologists we should not be blinkered in our attitude to HRT. Good for bone it might be but benefits to other organs are possibly of equal or greater significance. Cardiologists are beginning to take up the weapon of oestrogen replacement in their onslaught on cardiovascular disease, and it has been proposed that oestrogen status should be part of an overall cardiology assessment in the early postmenopausal woman with angina or hypertension. ${ }^{36}$ Deaths from myocardial infarction and cerebrovascular accident, as judged by the majority of a large number of publications, are reduced. Three recent large scale studies support a reduction in mortality of $25 \%$ or more. ${ }^{37-39}$ One notable exception is supposed to be the Framingham study, ${ }^{40}$ but caution is urged in the interpretation 
of the results of this study. The numbers taking HRT were small (17\%) and types and doses of oestrogens were not specified. It was the incidence of angina which doubled, no overall increase in mortality was observed; moreover, the incidence of myocardial infarction and electrocardiographic abnormalities was no greater in those receiving HRT. It is interesting that in the same study no relation was found between cigarette smoking and the incidence of angina. All the studies conducted so far are themselves perhaps hormone deficient in that oestrogen levels were not routinely measured.

High density lipoproteins are raised and low density lipoproteins reduced in women receiving oestrogen replacement. ${ }^{41-44}$ Oral oestrogens when absorbed undergo hepatic first-pass, which is believed to be responsible for the catabolism of low density lipoproteins, ${ }^{45-47}$ the effect possibly dependent on dose. ${ }^{48} 49$ Administering oestrogens by patch or implant, bypassing the liver and its metabolic effect on lipids, potentially reduces protection against cardiovascular and cerebrovascular disease. Oestrogens, however, have other properties over and above their effects on lipids. $\beta$-Oestradiol results in increases in tissue vascularity and cardiac output with reductions in vascular resistance and blood pressure. $^{\text {so }}$

\section{Oestrogens: contraindications and adverse} effects

The first major setback for oestrogen replacement therapy came when an association was found between its unopposed use and endometrial carcinoma. ${ }^{51}$ The normal risk to postmenopausal women is of the order of one in 1000 , rising to four to five per 1000 for every year oestrogens are taken. ${ }^{2}$ Although theoretically amenable to early detection and cure, ${ }^{53}$ the means to achieve this by dilatation and curettage every three years is unlikely to be acceptable to most women. It is anyway unnecessary as the addition of a progestogen on a cyclical basis to continuous oestrogen replacement results in a stepwise reduction in endometrial hyperplasia at seven and 10 days to 12 days when the risk of endometrial carcinoma is no greater than in a control group. ${ }^{54-56}$ The price to pay for combination HRT is withdrawal bleeds, yet these have a predictive value with regard to progestogen protection. In those who have been taking oral oestrogens for at least three months it has been shown that bleeding at day 11 correlates with endometrial secretory transformation, which obviates the need for diagnostic biopsy. ${ }^{57}$

The risk of thromboembolic disease to women receiving oestrogen replacement therapy is probably extremely small..$^{58}$ In those so predisposed there are theoretical advantages to administering oestrogens by implant or cutaneous patch in order to avoid the hepatic induction of clotting factors. A history of recent thromboembolism is a relative contraindication, but a single episode of deep vein thrombosis or pulmonary embolism in the distant past is not.

In general, oestrogens have no effect on blood pressure, ${ }^{59-61}$ and in most instances hyper- tension should not be considered a contraindication to or likely adverse effect from HRT. The advantages to lipoproteins, however, might modify the risk of myocardial infarctions or cerebrovascular accidents in those with stable mild to moderate hypertension.

One side effect of oestrogen therapy not to be overlooked is the development of cholesterol gall stones from effects on lipid metabolism. ${ }^{62}$ The need, on occasions, for abdominal surgery constitutes a further risk of HRT and although the advent of laparoscopic cholecystectomy makes the presence of gall stones less threatening, it is not to be ignored.

The main worries about oestrogen replacement relate to other hormone dependent malignancies. Whereas there is no overall increase in ovarian carcinoma, reports have been made of increases in the rare clear cell and endometrioid malignancies, ${ }^{63-66}$ although the results in these studies fell short of achieving statistical significance.

The charge against oestrogens inducing breast cancer, however, has not been unequivocally answered. Much of the early data relate to experience in the USA where unopposed oestrogens of types and in doses not now generally employed were for many years in routine use. The largest British study from Oxford ${ }^{39}$ showed a cumulative overall relative risk after 10 years of 1.59 with $95 \%$ confidence limits. A number of other studies have shown similar dose related relative risks of between $1 \cdot 3$ and $1 \cdot 9 .{ }^{67-70}$ On the other hand, three reports failed to show any increase in the risk of breast cancer. ${ }^{71-73}$ Yet another trial purported to reveal an even greater risk in those also receiving progestogens and raised concern about the relative carcinogenic effects of different oestrogens. ${ }^{74}$ These particular conclusions have been widely criticised on methodological grounds, and more questions were raised than were answered. Sadly, lack of financial support means there is currently no long term study underway in the United Kingdom to assess the dangers of breast cancer in those receiving oestrogen replacement therapy alone or in combination with progestogens. Speculation will, therefore, continue-an unhappy and inadequate state of affairs.

The conclusions to be drawn about the risk of breast cancer based on the data available are that short term oestrogen replacement-that is, less than five years, is safe; between 5 and 10 years the risk increases slightly; over 10 years it is perceptible but small and related to dose and possibly oestrogen type. It has to be said, however, that the precise risk remains undetermined.

As a result, family doctors, likely to be the largest group prescribing HRT, are understandably unsure about the side effect profile. Too often the risks and adverse effects are compared with those of the oestrogen-containing oral contraceptive pill. A recent survey of general practitioners ${ }^{75}$ confirmed this, but contrary to previous suggestions ${ }^{76}$ also showed their high level of understanding about HRT and osteoporosis. Despite this, disproportionate anxiety persists in many doctors, with further undermining of their confidence and that of 
their patients undoubtedly fuelled by the occasional irresponsible media report.

\section{Progestogens: advantages and disadvantages}

For the $80 \%$ of postmenopausal women with an intact uterus the addition of progestogen is the rule in order to protect against endometrial carcinoma. It is reasonable, therefore, to consider what, if any, effect progestogens themselves have on breast tissue, bones, heart, and blood vessels and any modulating or opposing effects they might have against oestrogen activity on those target organs.

Combination therapies currently use the progestogens norethisterone and norgestrel, and it is the 12 day progestogen phase of HRT which can cause equivalent symptoms to true premenstrual syndrome. For some women it is the occasional irregular bleeding, or the continuation or return of menstruation which proves undesirable. All too often combination HRT is abandoned too swiftly owing to troublesome side effects. Just as with oestrogens where one preparation is not universally acceptable, so changing the 'brand' of HRT and therefore the types of progestogen can be helpful. For others tailor-made regimens will be needed by combining an oestrogen with other progestogens, usually didrogesterone or medroxyprogesterone acetate, when the two tablets are prescribed separately and will not be available in a convenient calendar pack.

Progestogens being structurally similar to testosterone might be expected to counteract the cardioprotective effect of oestrogens and studies have shown this to be so. ${ }^{77-79}$ Fortunately, such opposition as does accrue appears small, and measurable, significant reductions in deaths from myocardial infarctions and cerebrovascular accidents remain. Again, their derivation from testosterone suggests that progestogens might have a positive effect on BMD, and a number of publications have supported this. ${ }^{80-89}$ Nonetheless, when used as the progesterone only contraceptive pill net bone loss has been recorded. ${ }^{90}$ Changes here, however, were related to oestrogen suppression rather than to the direct effect of progestogen itself on bone metabolism. The same study was limited in that other variables, most prominently smoking, were not evenly distributed among the three groups under consideration.

Despite the reservations expressed in the one study quoted earlier, ${ }^{78}$ actual modification of breast cancer risk is unknown. Protection by progestogens of one target organ against hormone dependent malignancy cannot necessarily be extended to another, since hormone receptors in breast and endometrium are biologically different. ${ }^{91}$ Current international opinion is of a lack of evidence to recommend progestogens routinely to women taking oestrogens who have had a hysterectomy. ${ }^{92}$

Progestogens, therefore, are endometrial guardians against carcinoma but have little, if any, extra value as part of HRT. The most sinister worry, breast cancer, remains apparently uninfluenced. Progestogens reduce the advantages, albeit to a small degree, to coronary and cerebral arteries and are responsible for the symptomatic side effects and withdrawal bleeds which cause a number of women to stop HRT. It remains to be seen, therefore, whether it is justifiable to continue combination HRT with presently used progestogens.

Developments over the next decade are likely to result in the production of newer, better tolerated preparations with the ability both to prevent monthly bleeds yet maintain endometrial protection. The recently introduced drug tibolone (Livial), possessing weak oestrogenic, progestogenic, and androgenic properties, possibly represents the first step in that direction, although the effect on BMD of this particular combination is considered to be relatively slight. ${ }^{93}$ Nonetheless, the lack of continuing menstruation is likely to make tibolone attractive to women and might influence their choice of HRT, which will not necessarily be as advantageous to bone metabolism as the more traditional combinations. To overcome this, suggestions that all women would be better having a hysterectomy at the menopause in order to take long term unopposed oestrogens smacks of 'Brave New World' and raises yet further ethical dilemmas for the poor gynaecologist. The technique of per vaginal endometrial resection might offer a compromise but, again, the question of surgery on the grounds of convenience alone, albeit with long term gains in mind, raises interesting moral, medical, and legal questions.

In the meantime, if progestogens are to continue, there is no choice but to persevere with those presently available. It should not be forgotten that women with a uterus who use patch or implant oestrogens must still take progestogen for 12 days each month, and knowledge of compliance with these regimens is incomplete.

Who should receive oestrogen replacement? The means to diagnose osteoporosis and monitor response to treatment are now available thanks to the advent of bone densitometry. Dual energy $x$ ray absorptiometry (DEXA) with a precision of less than $1 \%$ is currently the cheapest, safest, and most easily available technique to measure BMD and has revolutionised the investigation of osteoporosis. An additional benefit of DEXA will be to permit validation of existing treatments as well as to assess new therapeutic regimens. This will be of particular value to those perimenopausal women with a low BMD for whom HRT is contraindicated, unacceptable, or intolerable.

The technology to investigate osteoporosis is such that it is time to bury the idea that it can be recognised and managed on clinical grounds alone. Diagnosing osteoporosis and embarking on treatment without prior confirmation by BMD measurement is akin to giving streptokinase having diagnosed myocardial infarction with confidence but without first performing electrocardiography.

DEXA, therefore, is an indispensable diagnostic and research tool. Controversy about the use of BMD measurements relates to their 
usefulness in population screening programmes for perimenopausal women. It has been suggested that a bone density in excess of one standard deviation below the mean-that is, in the lowest quartile, for an age matched population at the menopause, identifies those at greatest risk from developing osteoporosis and, therefore, of future fracture. ${ }^{94}$ Further, since there is evidence to support the notion that one BMD measurement at a single site predicts future fracture risk at all susceptible sites, ${ }^{95-99}$ perimenopausal screening is superficially attractive. Greater accuracy in the prediction of risk might be possible if BMD measurement were combined with biochemical markers to determine slow or fast bone losers, ${ }^{100101}$ but this point remains unproved.

Doubt has been expressed, however, about whether the multifactorial nature of osteoporosis makes it a condition amenable to widespread screening to an extent that existing treatments will reduce future fracture rates. ${ }^{102} 103$ Large studies to consider the dilemma of screening are underway and until the results from Reid's and Purdie's groups in Aberdeen and Humberside respectively are known an open mind is required. A recent bulletin on osteoporosis screening issued to managers by a group commissioned by the Department of Health does not have the benefit of the information which will be forthcoming from the two large studies mentioned above. Unfortunately, the opinion of this group from the Leeds University Public Health School is open to misinterpretation. The danger being that the worth of BMD measurements in clinical practice as a whole will be questioned, thereby thwarting the responsible attempts by clinicians to secure bone densitometry for diagnostic use in patients with an increasingly common disease. After all, the success of HRT (and whatever other measures are ultimately agreed to be appropriate for the treatment or prevention of osteoporosis) can only be determined by measuring changes in BMD.

Yet, even if widespread screening becomes the accepted wisdom some degree of selectivity will be necessary on financial grounds, and with current manpower constraints the meeting of any significant increased demand seems unlikely. Until the dilemma about screening is resolved and in view of the limited DEXA facilities in the United Kingdom a compromise is necessary. It does seem sensible that all attempts should be made by general practitioners and relevant specialists to recognise on well established clinical grounds, crude as they might be, ${ }^{104-107}$ those most vulnerable to osteoporosis. Bone mineral density should be measured whenever possible, which might require women to travel to a centre where DEXA is available. Personal experience suggests that this is acceptable as perimenopausal women tend to be a highly motivated group and any repeat measurements are unlikely to be required at intervals of less than one year.

So far, the hypothesis has centred on the aim of providing HRT to preserve bone mass. Yet osteoporosis cannot be considered in isolation, for the benefits of oestrogen replacement must be viewed in a wider context. Promoting HRT only for those with low BMDs at the menopause is to neglect the significant reductions in cardiovascular and cerebrovascular disease possible in women over the age of 50 who take oestrogen replacement. It is irrational to discourage smoking and excess alcohol consumption and to exhort the benefits of adequate exercise and a good diet in all women, with the aim of reducing deaths from myocardial infarctions and cerebrovascular accidents, while only $25 \%$ have the added benefit of HRT for the single reason of minimising bone loss to prevent hip fracture at an advanced age. The quality of life too demands attention. Difficult to measure objectively, HRT is popular for reducing climacteric symptoms, inducing an enhanced sense of well being, for improving libido, and for maintaining an active sex life. ${ }^{108}$ To ignore these unquantifiable advantages is to undermine the importance of oestrogen replacement in most of the female population after the menopause.

\section{Strategy}

The arguments in favour of HRT are strong and the following approach by rheumatologists is suggested.

First, education of general practitioners about osteoporosis, HRT, and other treatment options is a priority. General practitioners are anxious to know more about osteoporosis and are under increasing pressure from their patients to discuss the menopause and provide HRT. The provision of intelligible and objective information about HRT plus the opportunity for a woman to discuss this with the family doctor, or an informed and interested member of the health professional team, should be as important an aim as education about smoking, alcohol consumption, and diet. It is only through contact with committed professionals that women can be expected to receive balanced information about oestrogen replacement. Publications have illustrated that perimenopausal women are often confused about HRT. ${ }^{109} 110$

Secondly, the commitment to HRT should not be short term. After five years, oestrogen replacement is associated with a reduction in hip fracture rate of the order of $50 \%,{ }^{14-16}$ so this should be the aim in all. For those at greatest risk, and particularly for women with an early menopause-that is, before the age of 46 , a good case can be made for continuing HRT for a decade. As there is a small but perceptible increase in breast cancer risk after this length of time on oestrogen replacement, the decision to continue will need to be considered on an individual basis. Over the next 10 years regimens are likely to alter, rheumatologists will become more knowledgeable about and experienced in the use of HRT, and its benefits to osteoporosis will be better understood thanks partly to the information that DEXA will provide. Similarly, in the not too distant future wider access to mammography is likely to permit adequate breast cancer screening for many more women taking HRT. This laudable requirement is perhaps encouraged thanks to $\mathrm{Sir}$ Donald 
Acheson's recent valedictory remarks from the Department of Health.

On all the evidence available the conclusion must be that promotion of HRT makes good sense on public health grounds. The financial costs/benefits are unproved, despite attempts which have been made in both the USA and the United Kingdom. ${ }^{111}{ }^{112}$ If the medical profession as a whole can be persuaded by the evidence in favour of HRT it is debatable whether knowledge of the economics should influence a doctor's decision to provide the best treatment for as many patients as possible. Any restriction to the provision of a high quality clinical service for osteoporosis on financial grounds will need to be made by politicians through the managers who administer the funds. Hansard of 17 October 1991 documents a reply by $\mathrm{Mr}$ MacGregor, leader of the House of Commons, to a question by the member of parliament for Bradford West about changes for osteoporosis screening, in which he states, 'The service is free to NHS patients . . . What is more, there is no waiting time for that service'-so we live in hope.

\section{Epilogue}

A knowledge of bone metabolism in osteoporosis on biological, cellular, and clinical levels provides intellectual opportunities to study a fascinating condition which threatens epidemic proportions. If this challenge is neglected it will fall to other disciplines to respond, with the rheumatologist left to tackle only the symptomatic relief and rehabilitation of those following crush fracture of the vertebrae and chronic disability from hip fracture-daunting and depressing prospects, important though they are.

The informed rheumatologist armed with densitometer, clinical acumen, and a few basic laboratory investigations is best placed to comprehend, investigate, and deal with those many aspects which influence osteoporosis and, in particular, to encourage HRT and monitor its beneficial effect. When the incidence of fractures substantially and perceptibly reduces then, and only then, will it be possible for rheumatologists to enjoy any sense of achievement in their struggle against the looming threat of osteoporosis.

Who knows, maybe then even Germaine Greer will be impressed.

1 Woolf V. A room of one's own. Bloomsbury: The Hogarth Press. 1929.

2 Albright F, Bloomberg E, Smith P H. Postmenopausa osteoporosis. Trans Assoc Am Physicians 1940; 55: 198-305.

3 Barlow D H, Grosset K A, Hart H, Hart D M. A study of 'Glasgow women' in the climacteric years. Br $\mathcal{F}$ Obstet Gynaecol 1989; 96: 1192-7.

4 Krolner B, Neilson S P. Bone mineral content of the lumbar spine in normal and osteoporotic women. Clin Sci 1982 62: $329-36$

5 Johnston C C, Hui S L, Witt R M. Early menopausal changes in bone mass and sex steroid. $\mathcal{I}$ Clin Endocrinol Metab 1985; 61: 905-11.

6 Riis B J, Rodbro P, Christiansen C. The role of serum con steroids and bone turnover in the concentration of sex steroids and bostmenopausal osteodevelopment and occurrence of postmenopay

7 Marshall D H, Crilly R G, Nordin B E C. Plasma endrostenedione and oestrone levels in normal and osteoporotic postmenopausal women. BMF 1977; ii: 177-9.
8 Davidson B J, Riggs B L, Wahner H W, Judd H L. Endogenous cortisol and sex steroids in patients with osteoporotic spinal fractures. Obstet Gynecol 1983; 61: 275-8.

9 Horsman A, Gallacher J C, Simpson P M, Nordin B C Prospective trial of oestrogen and calcium in postmenoprospective trial of oestrogen and calcium

10 Lindsay R, Aitken J M, McDonald E B, Anderson J B, Clark A C. Longterm prevention of osteoporosis by oestrogen. Lancet 1976; i: 1038-41.

11 Ettinger B, Jenant H K, Cann C E. Longterm estrogen replacement therapy prevents bone loss and fractures. Ann Intern Med 1985; 102: 319.

12 Christiansen C, Christiansen M S, McNair P, Hagen C, Stocklund K-E, Transbol I B. Prevention of early postmenopausal bone loss: control two years study. Eur $\mathcal{f}$ Clin Invest 1980; 10: 273-9.

13 Nachtigall L E, Nachtigall R H, Nachtigall R D, Beckman E M. Estrogen replacement therapy. A ten year prospective study in the relationship to osteoporosis. Obste spective study in the relation
Gynecol 1979; 53: $277-81$.

14 Hutchinson T A, Polansky S M, Feinstein A R. Postmenopausal oestrogens protect against the fractures of hip and distal radius. Lancet 1979; ii: 705-9.

15 Weiss N S, Ure B L, Ballard J H, Williams A R, Daling J R. Decreased risk of fractures in the hip and lower forearm with postmenopausal use of oestrogen. N Engl f Med 1980; 303: 1195-8.

16 Paganini-Hill A, Ross R K, Gerkins B R, et al. Menopausal oestrogen therapy in hip fractures. Ann Intern Med 1981 95: 28-31.

17 Lindsay $\mathrm{R}$, Hart D $\mathrm{M}$, Abdalla $\mathrm{H}$, Al-Azzawi $\mathrm{F}$. The interrelationship of bone loss and its prevention and fracture expression. In: Christiansen $C$, Johansen J S, Riis B J, eds. Osteoporosis: Proceedings of the Copenhagen international symposium. Copenhagen: Glostrup Hospital Denmark, 1987: 508-12.

18 Bijvoet O L M. Osteoporos Nederlands. Tijdschr Diergeneeskunde 1986; 130: 584-90.

19 Consensus development conference. Prophylaxis and treatment for osteoporosis. BMF 1987; 295: 914-5.

20 Anonymous. Osteoporosis [Editorial]. FAMA 1984; 252 $799-802$.

21 Consensus development conference: Prophylaxis and treatment of osteoporosis [Conference report]. Am $\mathcal{7} \mathrm{Med}$ 1991; 90: 107-10.

22 Royal College of Physicians. Fractured neck of femur: prevention and management. London: Royal College of Physicians, 1989.

23 Cummings S R, Kelsey J L, Nevit M C, O'Dowd K J. Epidemiology of osteoporosis and osteoporotic fractures. Epidemiol Rev 1985; 7: 178-208.

24 Grimley Evans J, Prudham D, Wandless I. A prospective study of fractured proximal femur-incidence and outcome 1979. Public Health 1979; 93: 235-41.

25 Beringer T R O, McSherry D M G G, Taggart H McA. A prospective study of fracture of the proximal femur in osteoporosis. In: Christiansen C, Johansen J S, Riis B J osteoporosis. In: Christiansen C, Johansen J S, Riis B J eds. Osteoporosis: Proceedings of the Copenhagen international symposium

26 Jensen G F, Stauffer R N, Kurland L, T. Epidemiology of postmenopausal spine and long bone fractures. Clin Orthop 1982; 166: 76-82.

27 Eriksen E F, Colvard D S, Berg N J, et al. Evidence of estrogen receptors in normal human osteoblast-like cells Science 1988; 241: 81 .

28 Fukayama S, Tashiian A H. Direct modulation by estradio with response of human bone cells ( $\mathrm{SaOS}-2)$ to human with response of human bone cells (SaOS-2) to human

29 Komm B S, Terpening C M, Benz D J, et al. Estrogen binding, receptor MRNA and biological response in osteoblast-like osteosarcoma cells. Science 1988; 241; $81-4$

30 Vaishnav R, Gallagher J A, Berrisford J N, et al. Direc effects of stanozolol and oestrogens in human bone cell culture. In: Christiansen C, Johansen J S, Riis B J, eds. Osteoporosis: Proceedings of the Copenhagen intemational symposium. Copenhagen: Glostrop Hospital, Denmark, 1984: 845-8.

31 Feyen J H M, Rais Z L. Prostaglandin production by Calvariae from Sham operated and oophorectomised rats: 121: 819-21.

32 Pacifici R, Rifas L, Teitelbaum S, et al. Spontaneous release of interleukin 1 from human blood monocytes reflects bone formation in idiopathic bone osteoporosis. Proc Natl Acad Sci USA 1987; 84: 4616-20.

33 Lindsay R, Hart D M, Clark D M. The minimum effective dose of estrogen for prevention of postmenopausal bon loss. Obstet Gynecol 1984; 63: 759-63.

34 Christiansen M S, Hagen C, Christiansen C, Transbol I Dose response evaluation of cyclic estrogen/gestagen in postmenopausal women. Am 7 Obstet Gynecol 1982; 144: 873-9.

35 Barlow D H, Abdalla H, Roberts A D G, et al. Longterm hormone implant therapy: hormonal and clinical effects. hormone implant therapy: horm.

36 Sarrel P M. Ovarian hormones: recent findings of cardiological significance. Cardiology in Practice 1991; 9 (2)

37 Bush T T. Barrett-Connor E, Cowan L D, et al. Cardiovascular mortality and non-contraceptive use of estrogen in women Circulation 1987; 75: 1102-9.

38 Paganini-Hill A, Ross R, Henderson B M. Postmenopausal 
oestrogen treatment in stroke: a prospective study. $B M \mathcal{F}$ 1989; 297: 519-22

39 Hunt K, Vessey M, McPherson K, Colman M. Longterm surveillance of mortality and cancer in women receiving hormone replacement therapy. Br $\mathcal{J}$ Obstet Gymaecol 1987; 94: 620-35.

40 Gordon T, Kannel W B, Hjortland M C, McNamara P M Menopause and coronary heart disease: the Framingham Menopause and coronary heart disease: the
study. Ann Intern Med 1978; 89: 157-61.

41 Godsland I F, Wynn V, Crook D, Miller N E. Sex, plasm lipoproteins and atherosclerosis. Am Heart $\mathcal{f}$ 1987; 114:

42 Tikkanen M J, Nikkila E A. Menopausal oestrogen therapy, serum lipoproteins in ischaemic heart disease. Lancet 1981; i: 13-9.

43 Ross R K, Mack T M, Paganini-Hill A, Arthur M, Henderson B E. Menopausal oestrogen therapy and protection from death from ischaemic heart disease. Lancet 1981; i: 858-60.

44 Walsh B W, Schiff I, Rosner B, Greenberg L, Ravnikar V, Sacks F M. Effects of postmenopausal estrogen replacement on the concentrations and metabolism of plasma ment on the concentrations and metabolism of p
lipoproteins. $N$ Engl f Med 1991; 325: 1196-204.

45 Eriksson $M$, Berglund L, Rudling $M$, Henriksson P, Angelin B. Effects of estrogen on low density lipoprotein metabolism in males. $\mathcal{F}$ Clin Invest 1989; 84: 802-10.

46 Veldhuis J D, Gwynn E J T. Estrogen regulates low density lipoprotein metabolism in cultured swine granulosis cells. Endocrinology 1985; 117: 1321-7.

47 Windler E, Kovanen P T, Chayo S, Brown M S, Harvel R J, Goldstein J L. The estradiol-stimulated lipoprotein receptor of rat liver. $\mathcal{F}$ Biol Chem 1980; 255: 10464-71.

48 Jensen J, Riis B J, Strom V, Nilas L, Christiansen C. Longterm effects of percutaneous estrogens in oral progesterone on serum lipoproteins in postmenopausal gesterone on serum lipoproteins in postmen
women. Am $\mathcal{F}$ Obstet Gynecol 1987; 156: 66-71.

49 Sharf M, Oettinger M, Lanir A, Kahana L, Yeshurun D. Lipid and lipoprotein levels following pure estradiol implantation in postmenopausal women. Gynecol Obstet Invest 1985; 19: 207-12

50 Magness R R, Rosenfeld C R. Local and systemic 17-beta estradiol effects on uterine and systemic vasodilatation. Am $\mathcal{F}$ Physiol 1989; 256 (suppl): E536-42.

51 Ziel H, Finkle W. Increased risk of endometrial carcinoma among the users of conjugated estrogen. $N$ Engl f Med 1975; 293: 1167-70.

52 Peterson H B, Lee N C, Rubin G L. Genital neoplasia. In: Mishell D R, ed. Menopause; physiology and pharmacology. Chicago: The Yearbook Medical Publishers, 1985: 275-98.

53 Chu J, Schweid A I, Weiss N S. Survival among women with endometrial cancer: a comparison of estrogen users and non-users. Am F Obstet Gynecol 1982; 143: 569-75.

54 Studd J W W, Thom $M$. Oestrogens and endometrial cancer. In: Studd J W W, ed. Progress in obstetrics and gynaecology, Vol 1. London: Churchill Livingstone, 1981: 182-98.

55 Whitehead M I, Townsend P T, Pryse-Davies J, et al. Effects of various types and doses of progestogens on the postmenopausal endometrium. $\mathcal{F}$ Reprod Med 1982; 27: $539-48$.

56 Persson I, Adami H-O, Bergkvist L, et al. Risk of endometrial cancer after treatment with oestrogens alone or in conjunction with progestogens: results of a prospective study. $B M \mathcal{F} 1989$; 298: 147-51.

57 Padwick M L, Pryse-Davies J, Whitehead M I. A simple method for determining the optimal dose of progestin in postmenopausal women receiving estrogens. $N$ Engl $\mathcal{J}$ Med 1986; 315: 930-4.

58 Nachtigall L E, Nachtigall R H, Nachtigall R D, Beckma E M. Estrogen replacement therapy II: A prospective study in the relationship to carcinoma and cardiovascular and metabolic problems. Obstet Gynecol 1979; 54: 74-9.

59 Wren B G, Brown L B, Routledge D A. Differential clinical response to oestrogens after menopause. Med $\mathcal{f}$ Aus 1982; 2: 329-32.

60 Hammond C B, Jelousek F R, Lee K L, Creasman W T, Parker R T. Effects of longterm estrogen replacement therapy. II. Neoplasia. Am J Obstet Gymecol 1979; 133: 537-47.

61 Pfeffer R I, Kurosaki T T, Charlton F K. Estrogen use and blood pressure in later life. Am $\mathcal{Y}$ Epidemiol 1979; 110: 469-78.

62 Boston Collaborative Drug Surveillance Program. Surgically confirmed gallbladder disease, venous thromboembolism and breast tumours in relation to postmenopausal estrogen therapy. N Engl f Med 1974; 290: 15-9.

63 Cramer D W, Devasa F. W, Welch W R. Trends in the incidence in endometrioid and clear cell cancers of the ovary in the United States. Am F Epidemiol 1981; 114: 201-8.

64 Weiss N S, Lyon J L, Krishnamurthy F, et al. Noncontraceptive estrogen use in the occurrence of ovarian cancer. $\mathcal{F}$ Natl Cancer Inst 1982; 68: 95-8.

65 Cramer D W, Hutchison G B, Welch W $R$, et al. Determinance of ovarian cancer risk. Reproductive experiences and family history. $\mathcal{F}$ Natl Cancer Inst 1983 71: 711-6.

66 La Vecchia C, Liberati C, Franceschi S. Non-contraceptive estrogen use in the occurrence of ovarian cancer. $\mathcal{F}$ Nat Cancer Inst 1982; 69: 1207.

67 Ross R K, Paganini-Hill A, Gurkins V A, et al. A case controlled study of menopausal estrogen therapy and breast cancer. $\mathcal{Y} A M A$ 1980; 243: 1635-8.

68 Hoover R, Glass A, Finkel W D, Azevedo D, Milne K.
Conjugated estrogens and breast cancer risk in women f Natl Cancer Inst 1981; 67: 815-20.

69 Hiatt R A, Bawol R, Friedman G D, Hoover R. Exogenous estrogen in breast cancer after bilateral oophorectomy. Cancer 1984; 54: 139-44.

70 Brynton L A, Hoover R, Fraumeni J F. Menopausa oestrogens and breast cancer risk; an expanded case controlled study. Br $\mathrm{f}$ Cancer 1986; 53: 825-32.

71 Kelsy J L, Fischer D B, Halford T R, et al. Exogenous estrogens and other factors in the epidemiology of breast estrogens and other factors in the epidemiology
cancer. $\mathcal{I}$ Natl Cancer Inst 1981; 67: 327-33.

72 Kaufman D W, Miller D R, Rosenberg L, et al. Noncontraceptive estrogen use and the risk of breast cancer. fAMA 1984; 252: 63-7.

73 Wingo P A, Layed P M, Lee N C, Rubin G, Ory H W. The risk of breast cancer in postmenopausal women who have used estrogen replacement therapy. $\mathcal{F} A M A 1987 ; 257$ 209-15.

74 Bergkvist L, Adami H-O, Persson I, Hoover R, Shaire R C. Risk of breast cancer after estrogen and estrogenprogestin replacement. $N$ Engl f Med 1989; 321: 293-7.

75 Palferman T G. Abstracts: XII European Congress of Rheumatology. 1991: FP 37-377.

76 Griffin J. Osteoporosis and the risk of fracture. London: Office of Health Economics, 1990

77 Hirvonen E, Malkonen M, Manninen V. Effects of different progestogens on lipoproteins during postmenopausal replacement therapy. $N$ Engl f Med 1981; 304: 560-3.

78 Jensen J, Nilas L, Christiansen C. Cyclic changes in serum cholesterol and lipoprotein following different doses of combined post-menopausal hormone replacement combined post-menopausal hormone replace

79 Ottosson U B, Johansson M D, von Scholtz B. Subfraction of high density lipoprotein cholesterol during estrogen replacement therapy; a comparison between progestogen and natural progesterone. Am $\mathcal{F}$ Obstet Gynecol 1985; 151: 746-51

80 Lindsay R, Hart D M, Purdie D, et al. Comparative effects of estrogen and progestogen on bone loss in postmenopausal women. Clin Sci 1978; 54: 1193-5.

81 Abdalla H I, Hart D M, Lindsay R, et al. Prevention of bone loss in postmenopausal women by norethisterone. Obstet
Gymecol 1985; 66: 789-92.

82 Prior J C, Vigna Y M, Shechtrem T, Burgess A E. Spinal bone loss and ovulatory disturbances. $N$ Engl $\mathcal{f} \mathrm{Med}$ 1990; 323: 1221-7.

83 Mandel F P, Davidson B J, Erlik Y, Judd H L, Meldrum $D$ R. Effect of progestins on bone metabolism in postmenopausal women. $\mathcal{A}$ Reprod Med 1982; 27: 511-4.

84 Selby P L, Peacock M, Barkworth S A, Brown W B, Taylor $G$ A. Early effects of ethinyl oestradiol and norethisterone treatment in postmenopausal women on bone resorption and calcium regulatory hormones. Clin Sci 1985; 69: 265-71.

85 Prior J C. Progesterone as a bone-trophic hormone. Endocrinol Rev 1990; 11: 386-98.

86 Loho R A, McCormick W, Singer F, Roy S. Depo-medroxyprogesterone acetate compared with conjugated estrogens for the treatment of post-menopausal women. Obstet Gynecol 1984; 63: 1-5

87 Abdalla H I, Hart D M, Lindsay R, Leggate I, Hook A. Prevention of bone mineral loss in postmenopausal women by norethisterone. Obstet Gynecol 1985; 66: 789-92.

88 Riis B J, Christiansen C, Johansen J S, Jacobson J. Is it possible to prevent bone loss in young women with lutenizing hormone-releasing hormone agonists? f Clin Endocrinol Metab 1990, 70:920-4.

89 Gallagher J C, Kable W T, Goldgar D. Effect of progestin therapy on cortical and trabecular bone: comparison with estrogen. Am F Med 1991; 90: 171-8.

90 Cundy T, Evans M, Roberts H, Wattie D, Ames R, Reid $I R$. Bone density in women receiving depomedroxyprogesterone acetate for contraception. BM J 1991; 303:
$13-6$.

91 Anderson T J, Furgusson D J P, Raab G M. Cell turnover in the resting human breast: influences of parity, contrathe resting human breast: influences of parity, contraceptive

92 Whitehead M I, Lobo R. Consensus conference: progestogen use in postmenopausal women. Lancet 1988; ii: 1243-4.

93 Lindsay R, McHart D, Kraszewski A. A prospective double-blind trial of synthetic steroid (Org OD14) for preventing postmenopausal osteoporosis. BMF 1980; 280: 1207-9.

94 Hui S L, Slemenda C W, Johnson C C. Baseline measurements of bone mass predicts fracture in white women. Ann Intern Med 1989; 111: 362-7.

95 Gardsell P, Johnell O, Nilsson B E. Predicting fractures in women using forearm bone densitometry. Calcif Tissue Int 1989; 44: 235-42.

96 Ross P D, Wasnich R D, Vogel J M. Detection of prefracture spinal osteoporosis using bone minera absorptiometry. F Bone Min Res 1988; 3: 1-11.

97 Wasnich R D, Ross P D, Heilbrun L K, Vogel J M Prediction of postmenopausal fracture risk with use of bone mineral measurements. Am $\mathcal{F}$ Obstet Gynecol 1985; 153: $745-51$.

98 Jensen G F, Christiansen C, Borsen J, Hegedus V, Transbol I. Relationship between bone mineral content and frequency of postmenopausal fracture. Acta Med Scand 1983;213. 61-3.

99 Smith D M, Kahairim M R A, Johnston C C. The loss of bone mineral with aging and its relationship to risk of fracture. $\mathcal{F}$ Clin Invest 1975; 56: 311-88. 
100 Hansen M A, Overgard K, Riis B J, Christiansen C. Role of peak bone mass and bone loss in postmenopausal osteoporosis: twelve year study. BMF 1991; 303: 961-4.

101 Christiansen C, Riis B J, Rodbero P. Prediction of rapid bone loss in postmenopausal women. Lancet 1987; i: 1105-8.

102 Law M R, Wald N J, Meade T W. Strategies for prevention of osteoporosis and hip fracture. BMf 1991; 303: 453-9.

103 Raffle A E, Cooper C. Bone density screening for osteoporosis. Lancet 1990; 336: 242.

104 Mazess R B, Barden H S. Bone densitometry for diagnosis and monitoring osteoporosis. Proc Soc Exp Biol Med 1989: 261-71.

105 Cohn A J, Vaswani A N, Yel J H, Yuen K, Ellis K. Risk factors for postmenopausal osteoporosis. Am $\mathrm{f} \mathrm{Med}$ 1985; 78: 95-100.

106 Elders P J M, Netelenbos J C, Lips P, et al. Perimenopausal bone mass and risk factors. Bone Miner 1989; 7: 289-99.
107 Slemenda C W, Hui S L, Longcope C, Wellman H, Johnston Jr C C. Predictors of bone mass in perimen pausal women. Ann Intern Med 1990; 112: 96-101.

108 Hunt K. Perceived values of treatment among a group of longterm users of hormone replacement therapy. J $R$ Coll Gen Pract 1988; 38: 398-401.

109 Draper J, Roland M. Perimenopausal women's views on taking hormone replacement therapy to prevent osteoporosis. $B M \mathcal{F}$ 1990; 300: 786-8.

110 Price V H, Wallace W A, Elliott C A, Macpherson M B A. BMF 1990; 300: 1196.

111 Roche $M$, Vessey $M$. Hormone replacement therapy in the menopause: benefits and costs. In: Osteoporosis. London: Royal College of Physicians, 1990.

112 Weinstein M C, Schiff I. Cost effectiveness of hormone replacement therapy in the menopause. Obstet Gynecol Surv 1983; 38: 445-55. 